ICEEPSY 2021

$12^{\text {th }}$ International Conference on Education \& Educational Psychology

\title{
PRESCHOOL EDUCATION DURING THE COVID-19 PANDEMIC IN THE CZECH REPUBLIC AND SWEDEN
}

\author{
Veronika Gajdová (a), Alena Srbená (b)* \\ *Corresponding author
}

(a) Faculty of Education, Palacký University Olomouc, Olomouc, Czech Republic, veronika.gajdova01@upol.cz

(b) Faculty of Education, Palacký University Olomouc, Olomouc, Czech Republic, alena.srbena@upol.cz

\begin{abstract}
The text presents a part of a broader research study carried out at the Faculty of Education, Palacký University Olomouc in cooperation with foreign partners. Its aim is to analyse and compare the impact of the measures against the spread of COVID-19 on preschool education in selected European countries. The paper describes an initial comparative study involving the Czech Republic and Sweden in order to analyse and compare the impact of the anti-epidemic measures on the conditions and functions of preschool education in the context of starting compulsory education. The research method is a qualitative text content analysis, followed by open coding and formulation of analytical categories and their comparison according to the principles of comparative pedagogy. The data source are international and national documents relevant to the research problem. Available data suggest that the impact of the anti-epidemic measures on preschool education varies both in the achievement of the functions of preschool education and in the conditions of nursery schools during the epidemic. The outcome of the study is a series of suggestions concerning the impact of the epidemic on preschool education in the Czech Republic and Sweden including a comparison. The paper also includes recommendations for the training of future teachers during a pandemic.
\end{abstract}

2672-8141 @ 2021 Published by European Publisher.

Keywords: Anti-epidemic measures, functions and conditions of preschool education, children, nursery schools, preparation for compulsory education 


\section{Introduction}

The coronavirus pandemic has affected education in both the Czech Republic and Sweden. The functions and conditions of preschool education have changed. In the Czech Republic, nursery schools were primarily affected by the anti-epidemic measures aimed at reducing contact between individuals, both between children and between teachers and parents. Nursery schools were closed for 50 working days by a governmental regulation. Distance education was a novelty for nursery as well as elementary schools (Bryndová et al., 2021; MŠMT, 2021b). At the same time, it had an impact on the effectiveness of education as a result of limited contact with children, selection of educational strategies, content, etc. (Provázková Stolinská \& Filípková, 2021). Sweden, however, took different measures. Nursery schools were not closed but hygiene and organizational measures were taken instead. Similarly, these measures affected the normal operation of nursery schools. In both countries, coronavirus had an effect on the operation, functions and conditions of preschool establishments, albeit in a different way. A comparison of education in the Czech Republic and Sweden reveals the differences in the way children were educated during the epidemic, which is extremely valuable for the training of future teachers and for the preparation for similar situations in the future.

\subsection{Functions of preschool education}

The nursery school is a place where children socialize and are prepared for personal, occupational and civil life. The functions were selected according to Šmelová (2006) as follows. Educational function: harmonious development of the child, the child's personality and learning, preconditions for further education. Caring function: professional care, child's self-care, care for the child's health and environment. Socialization function: secondary socialization closely linked to family education. Integration function: foundations of key competences, preconditions for lifelong learning. Personalization function: supporting the individuality of every child.

\subsection{Conditions of preschool education}

The monitored conditions relate to material, psychosocial, organizational, staffing and pedagogical conditions, regimen and parental involvement. These conditions were selected according the amount of information obtained and its occurrence in documents. Material conditions: suitable outdoor and indoor areas, furniture, toys, generally appropriate material facilities in nursery schools. Regimen: provision of a rich and balanced diet, sufficient physical activity, rest and sufficient time spent outdoors. Generally, children's healthy lifestyle is supported. Psychosocial conditions: school climate and classroom atmosphere. A safe, calm, respectful, balanced and secure environment for nursery schools. Organizational conditions: organizational arrangement of nursery schools including the daily schedule, order and programme. Staffing and pedagogical conditions: staff with the required professional qualification. Parental involvement: parental involvement in preschool education through partnership cooperation (RVP PV, 2018). 


\subsection{Anti-epidemic measures in preschool education}

At the end of 2019/2020 and during 2020/2021, anti-epidemic measures were introduced in nursery schools against the spread of Covid-19. The hygiene measures ordered nursery schools to meet the new requirements in order to ensure safe education. The anti-epidemic measures significantly differed between the Czech Republic and Sweden including the measures in nursery schools. The measures in Sweden were much less stringent compared with the rest of Europe. The Swedish government issued especially recommendations and relied on the responsibility of the citizens. In the Czech Republic, the state of emergency was announced several times, the country was in quarantine and much stricter measures applied compared with Sweden. In addition to the recommendations, bans were announced that limited the lives of the citizens in order to prevent the spread of Covid-19. Unfortunately, this affected nursery schools both in the Czech Republic and Sweden (Bergkvist et al., 2021; Bryndová et al., 2021).

\subsubsection{Anti-epidemic measures in preschool education in the Czech Republic}

For most of the epidemic, preschool establishment in the Czech Republic were open for all children. They were only closed if quarantined or if decided by the director. The Ministry of Education, Youth and Sports (hereinafter MEYS) issued guidelines on how preschool education should be implemented pursuant to the applicable anti-epidemic measures and issued recommendations for distance education for children in the compulsory year. The situation deteriorated so much in 2021 that the government also closed nursery schools and regular attendance was replaced with distance education for up to 50 working days. Nursery schools were closed from 27 February to 10 May 2021 (Bryndová et al., 2021). Ten days later, all children were allowed to attend without the obligation of testing. For most of the time, teachers and parents had to wear masks when children came and left and parents were often prevented from entering the school building. The MEYS issued guidelines recommending outdoor activities and a sufficient supply of soap, disinfection and disposable wipes on toilets. The intensity of cleaning must be increased, classrooms frequently ventilated and additional hygiene measures taken (MŠMT, 2020).

Designated nursery schools were in operation for children of parents of specific professions. If a preschool child was ill with Covid-19, they had to stay at home for at least 14 days (MŠMT, 2021b). Parents also had the opportunity to educate their children at home in order to prevent the spread of the disease (MŠMT, 2021c). On 1 April 2021, the MEYS issued a guideline on the first stage of reopening. Nursery schools opened only for children in the last compulsory year of preschool education. The maximum number of children in a group was 15. Children did not have to wear face masks or respirators but had to be tested once a week. Staff had to wear respirators and were tested twice a week using an antigen test or once a week by a PCR test. From 10 May 2021 all children were allowed in nursery schools without testing (MŠMT, 2021b).

\subsubsection{Anti-epidemic measures in preschool education in Sweden}

In Sweden, preschool establishments were open for all children. Children who were ill and posed a risk of infecting others had to stay at home. Healthy children without symptoms could continue to attend nursery schools. Preschool establishments are important for the development and well-being of young 
children and therefore, it is crucial to find a balance between the needs of preschool children and the antiepidemic measures. It has turned out that school activities are not the driving force for the spread of the infection and the rate of Covid-19 among staff in preschool establishments is similar to other professional groups. Children attend preschool establishments under hygiene measures and organizational conditions adapted accordingly. Parents also had the opportunity to educate their children at home in order to prevent the spread of the disease (IFAU, 2021). During the whole period, children, teachers as well as non-teaching staff did not have to wear face masks or respirators. If a preschool child was ill with Covid-19, they had to stay at home for at least 7 days (Folkhalsomyndigheten, 2021a, 2021b).

To ensure safe operation of preschool establishments, the Swedish Public Health Agency issued guidelines for preventive measures in preschool establishments. They included stricter hygiene with access to soap, paper wipes and hand disinfection. Other measures concerned greater distances between chairs in classrooms, dining rooms and other places but no distance in meters was specified. For example, schools adopted lunch arrangements so that all children did not eat at the same time. Also, the beginning and end of the school day was adjusted to prevent a large number of people gathering. Preschool establishments had to minimize their activities including open days, meetings with parents or performances but these activities were not strictly prohibited. The education was supposed to take place outdoors. Preschool establishments were supposed to inform children about how the virus is transmitted and how they should behave (Folkhalsomyndigheten, 2020, 2021b).

\subsubsection{Summary of anti-epidemic measures in nursery schools}

Nursery schools in the Czech Republic and Sweden adopted anti-epidemic measures, concerning particularly hygiene and organization. For clarity, the measures in nursery schools are shown in Table 1.

Table 1. Measures to prevent the spread of Covid-19 in nursery schools in 2019/2020 and 2020/2021 in the Czech Republic and Sweden

\begin{tabular}{|c|c|c|}
\hline ANTI-EPIDEMIC MEASURES & CZECH REPUBLIC & SWEDEN \\
\hline $\begin{array}{l}\text { Increased hygiene measures } \\
\text { (disinfection, disposable wipes, soap) }\end{array}$ & YES & YES \\
\hline Distance according to applicable standard & $\begin{array}{c}\text { YES } \\
\text { (at least } 2 \text { meters) }\end{array}$ & $\begin{array}{c}\text { YES } \\
\text { (distance not determined) }\end{array}$ \\
\hline $\begin{array}{l}\text { Wearing masks } \\
\text { (at least one month) }\end{array}$ & $\begin{array}{c}\text { YES } \\
\text { (teachers and parents) }\end{array}$ & NO \\
\hline $\begin{array}{l}\text { Mandatory testing of children for COVID-19 } \\
\text { (at least one week) }\end{array}$ & YES & NO \\
\hline $\begin{array}{l}\text { Mandatory testing of staff for COVID-19 } \\
\text { (at least one month) }\end{array}$ & YES & NO \\
\hline Change to the education programme & $\begin{array}{c}\text { YES } \\
\text { (outdoor education, } \\
\text { no singing) }\end{array}$ & NO \\
\hline Change to the implementation of education & $\begin{array}{c}\text { YES } \\
\text { (distance form) }\end{array}$ & NO \\
\hline School events, performances & $\begin{array}{c}\mathrm{NO} \\
\text { (prohibited) }\end{array}$ & $\begin{array}{c}\mathrm{NO} \\
\text { (recommended) }\end{array}$ \\
\hline $\begin{array}{l}\text { Social events } \\
\text { (theatre, library) }\end{array}$ & $\begin{array}{c}\mathrm{NO} \\
\text { (prohibited) }\end{array}$ & $\begin{array}{l}\mathrm{NO} \\
\text { (recommended) }\end{array}$ \\
\hline
\end{tabular}




\begin{tabular}{lcc}
\hline $\begin{array}{l}\text { Closure of nursery schools due to the absence of } \\
\text { children or staff }\end{array}$ & YES & YES \\
$\begin{array}{l}\text { Closure of nursery schools by governmental } \\
\text { regulation }\end{array}$ & YES & NO \\
\hline $\begin{array}{l}\text { Note: The information in Table 1 suggests that the measures in the Czech Republic were stricter than in } \\
\text { Sweden and had a greater effect on the process of education in nursery schools. }\end{array}$
\end{tabular}

\subsection{Preparation of children for school attendance in both countries}

The preparation of children for school attendance in nursery schools is an integral part of preschool education, but the anti-epidemic measures made it much more difficult. Czech nursery schools were under distance education for 50 working days and proceeded according to MEYS guidelines. This was the first experience with distance education and caused specific difficulties. In Sweden, education continued fulltime and nursery schools remained open. However, the preparation for school attendance differs in Sweden and is implemented through a compulsory class as part of primary education. Generally, however, compulsory preschool education in both countries applies to children aged 5 to 7 years (MŠMT, 2021a; Skolverket, 2011).

\subsubsection{Compulsory distance preschool education in the Czech Republic}

In the Czech Republic, preschool education has been compulsory and free of charge since 2017 and applies to children aged five years and older. The scope of compulsory education is set for at least 4 hours per day on working days (Act No. 561/2004 Coll.). Children in the compulsory preschool year had distance education for at least 50 working days on the basis of the guidelines for distance education. Another change related to communication, which was redirected from teacher-child to teacher-parents. The main responsibility for education was shifted to parents who were supposed to educate their children at home according to the teacher's instructions. Also, teachers had to carry out educational diagnostics in a different way. Distance education included both online or offline activities. In the case of online education, synchronous meetings were recommended for only 30 minutes once a week, which is a big difference compared with the compulsory 20 hours per week full-time. The results of education were tested especially through photographs of children's work and in other ways as selected by nursery schools. As a result, educational diagnostics was limited and lacked for example observation or interviews and instead focused on content analysis of children's work (MŠMT, 2021a).

\subsubsection{Compulsory full-time preschool education in Sweden}

In Sweden, compulsory preschool education does not take place in nursery schools but preschool classes in primary school. The obligation to attend the preschool class applies to children aged 6 to 7 years and was enacted in 2018 (Ježková et al., 2011). The preschool class and primary school have the same educational document but the chapters are separate. There is no curriculum or timetable specified for the preschool class. Its programme is between nursery and primary school (Utbildningsdepartementet, 2021). The required qualification for teachers in the preschool class is a university degree in preschool education, 
preschool class or primary school (grade 1 to 3 ). The preparation for compulsory education is part of the nursery school education programme but is not part of compulsory education (Förordning, 2011).

\section{Problem Statement}

What is the impact of the anti-COVID measures on the conditions and functions of preschool education in the Czech Republic and Sweden in relation to children's preparation for compulsory education? The World Health Organization (WHO), the United Nations Educational, Scientific and Cultural Organization (UNESCO) and the United Nations Children's Fund (UNICEF) emphasised that in order to support the overall well-being, health and safety of children, the key goal should be to keep schools open. School closures have a negative impact on children's health and well-being as well as educational outcomes (World Health Organization, 2021). In view of these facts, we focused on the conditions and functions of preschool education, as they are an integral part of education and affect the results of education. In April 2021, the primary school enrolment procedure took place in the Czech Republic suggesting an increased number of children with postponement of compulsory education. The child psychologist Nesnídal reported a decrease in children's school readiness due to the anti-epidemic measures related to Covid-19 (Deník Právo, 2021). The study focuses on the effects of the anti-epidemic measures in the Czech Republic and Sweden that relate to the education of children in nursery schools and their preparation for compulsory education.

\section{Research Questions}

The research questions are based on the research problem and goal:

- How do the anti-COVID measures affect the conditions and functions of preschool education?

- How do the anti-COVID measures affect children's preparation for starting compulsory education?

\section{Purpose of the study}

The text focuses on a comparative study involving the Czech Republic and Sweden. The aim of the study is to analyse and compare how the anti-epidemic measures affected the conditions and functions of nursery schools with an emphasis on children's preparation for compulsory education in both countries.

\section{Research methods}

The research was of a qualitative design based on the method of text content analysis. The content analysis focused on written texts including international and national documents relevant to the research problem. A set of texts was extracted based on deliberate sampling according to characteristics associated with the research problem. The content analysis was applied according to Gavora (2000) as follows: semantic units and analytical categories were determined and analytical categories quantified and interpreted. In the interpretation of the analytical categories, the card laying technique was used. 
The data analysis was based on open coding, formulation of analytical categories and their subsequent comparison according to the principles of comparative pedagogy: pluralism, comparability, contextuality and scientific quality. The basic precondition in a comparison is comparability, systematization and searching for causalities (Vlček, 2015). In the context of this paper, the comparand was a set of documents from the Czech Republic and the comparate was a set of documents from Sweden concerning preschool education in relation to the anti-epidemic measures during the Covid-19 epidemic. In the context of comparative pedagogy, the procedure according to Bereday was applied (as cited in Vlček, 2015). The research problem was formulated, data collected, findings described and interpreted, a juxtaposition framework developed and a comparison and search for causalities performed.

All of the documents below (see Table 2, Table 3 and Table 4) were subjected to a content analysis and are no longer referenced in data interpretation.

Table 2. Main international documents used for content analysis

1 Updated document Policy Responses in Czech Republic about Covid-19 administered by the European Commission, World Health Organization and Health System Response Monitor

2. Updated document Policy Responses in Sweden about Covid-19 administered by the European

2. Commission, World Health Organization and Health System Response Monitor

3. COVID-19 in children and the role of school settings in COVID-19 transmission issued by the

3. European Centre for Disease Prevention and Control

4. Schooling during COVID-19: recommendations from the European Technical Advisory Group for schooling during COVID-19 issued by the World Health Organization

Table 3. Main national documents for content analysis from the Czech Republic

Documents issued primarily by the Ministry of Education, Youth and Sports and the Czech School Inspectorate:

1. Guidelines for distance education in nursery schools

2. Operation of nursery schools until the end of $2019 / 2020$

3. Operation of schools and school establishments in 2020/2021 with respect to Covid-19

4. Framework education programme for preschool education

5. Thematic report of the Czech School Inspectorate Education in nursery schools during the state of emergency

6. Act No. 561/2004 Coll., on preschool, elementary, secondary, higher vocational and other education, as amended

Table 4. Main national documents for content analysis from Sweden Documents issued primarily by Skolverket (National Agency for Education) and Folkhalsomyndigheten (Swedish Public Health Agency):

1. Covid-19 in children and adolescents - A compilation of knowledge (version 3)

2. Covid-19- Preschools

3. Curriculum for the preschool, Lpfö 98

4. Swedish children and youth during the COVID-19 pandemic - Evidence from research on childhood environment, schooling, educational choice and labour market entry

5. Education Act Skollag (2010:800) 


\section{Findings}

The data collected were used for the juxtaposition and presented in the tables. The tables below (see Table 5 and Table 6) show which anti-epidemic measures disrupted the functions and conditions of preschool education and how. Education was disrupted in both countries but the degree differed according to the measures adopted. The disruption also concerned the preparation of children for compulsory education in the Czech Republic and the preparation of children for the compulsory preschool class in Sweden (see Table 7). The greatest disruption was observed in the conditions of nursery schools, followed by functions and overall operation of nursery schools.

\subsection{Juxtaposition of the information on preschool education functions}

The information of the school year 2019/2020 and 2020/2021 is shown in Table 5:

Table 5. Juxtaposition of the functions of preschool education in the context of the anti-epidemic measures in both countries

\begin{tabular}{|c|c|c|}
\hline Selected Criteria & Czech Republic & Sweden \\
\hline Educational function & $\begin{array}{c}\text { Risk of non-holistic child } \\
\text { development } \\
\text { Required achievement by family }\end{array}$ & $\begin{array}{c}\text { Holistic child development } \\
\text { Possible achievement by family }\end{array}$ \\
\hline Caring function & $\begin{array}{l}\text { Care for one's health } \\
\text { Restrictions on physical contact } \\
\text { with children }\end{array}$ & $\begin{array}{l}\text { Care for one's health } \\
\text { Restrictions on physical contact with } \\
\text { children }\end{array}$ \\
\hline Socialization function & $\begin{array}{c}\text { Distance education } \\
\text { Preventing social contact }\end{array}$ & $\begin{array}{l}\text { Full-time education } \\
\text { Restrictions on social contact }\end{array}$ \\
\hline $\begin{array}{l}\text { Integration function } \\
\text { (lifelong learning) }\end{array}$ & $\begin{array}{l}\text { Threat to systematic school } \\
\text { preparation for enrolment in primary } \\
\text { school }\end{array}$ & $\begin{array}{l}\text { Systematic preparation for enrolment } \\
\text { in primary school }\end{array}$ \\
\hline Personalization function & $\begin{array}{l}\text { Risk of non-achievement of an } \\
\text { individualized approach in education }\end{array}$ & Individualized approach in education \\
\hline
\end{tabular}

Note: The information in Table 5 is compared in the next section.

\subsubsection{Common and different features of selected functions in both countries}

\subsubsection{Educational function}

Common features: The achievement of the educational function was affected in both countries. In the Czech Republic, this primarily concerned the way of education which was most affected by the transition from full-time education to distance education. In Sweden, the changes in education were not so significant; teachers' sick leave affected the continuity of the education process.

Different features: In the Czech Republic, distance preschool education lasted for 50 working days and affected holistic child development due to the absence of some activities (singing, speech development). The education was partially transferred to parents. The educational process was also affected by the wearing of respirators by teachers, which was a barrier to the development of speech skills including foreign language (the impossibility of observing the correct articulation and mouth movements). In Sweden, 
full-time education in nursery schools continued with a potential disruption of the educational function during the voluntary home education.

\subsubsection{Caring function}

Common features: In both countries, the achievement of the caring function was jeopardized by the greater distance from children in order to avoid infection. Close contact with children was limited to necessary operations (wiping at the toilet, etc.). Children's self-care was restricted by preventing selfservice provision of meals and drinks. On the contrary, children's care for their health improved due to the stricter hygiene requirements supported by teachers.

Different features: Nursery schools in both countries adopted similar anti-epidemic measures. As a result, no differences were identified in the documents relating to the caring function.

\subsubsection{Socialization function}

Common features: This function was jeopardized particularly among children and teachers who were ill and had to stay at home. The mandatory home quarantine was 14 days in the Czech Republic 7 days in Sweden.

Different features: The way of education differed between the two countries. For most of the school year, education was full-time in both countries. In the Czech Republic however, distance education lasted for over a month. Children were without social contact and did not meet other children or teachers. The socialization function was not achieved, or to a minimum extent. In Sweden, full-time education was retained throughout the whole epidemic, so this function was achieved.

\subsubsection{Integration function}

Common features: In this respect, nursery schools in both countries adopted different anti-epidemic measures (distance education). Therefore, no common features were identified.

Different features: In the Czech Republic, the systematic school preparation of children for enrolment in primary school was jeopardized. Distance education and the possibility for voluntary home education prevented school preparation and jeopardized the development of school readiness, which is one of the important aspects of entering primary school. In Sweden, education was full-time and the systematic preparation of children for primary school was jeopardized by voluntary home education.

\subsubsection{Personalization function}

Common features: Preschool education in both countries emphasises respect for the individual needs of every child. During full-time education under the anti-epidemic measures, children were approached individually according to their capabilities and that of nursery schools.

Different features: Distance education in the Czech Republic revealed the risk of non-achievement of an individualized approach in education. The guidelines for distance education are general and their observance was in the competence of directors. Most nursery schools opted for offline activities designed particularly for each age category. As far as individual needs and capabilities of children are concerned, the 
activities could not have been individualized due to the absence of quick feedback. In Sweden, full-time education in nursery schools continued with a potential disruption of the individualized approach during the voluntary home education.

\subsection{Juxtaposition of the information on preschool education conditions}

The information of the school year 2019/2020 and 2020/2021 is shown in Table 6:

Table 6. Juxtaposition of the conditions of preschool education in the context of the anti-epidemic measures in both countries

\begin{tabular}{lcc}
\hline Extracted Criteria & Czech Republic & Sweden \\
\hline Material conditions & Distances - space adjustments & Distances - space adjustments \\
& Hygiene aids & Hygiene aids \\
Wearing masks, tests & Without face masks or tests \\
Daily regimen & Outdoor activities preferred & Outdoor activities preferred \\
& Promotion of a healthy lifestyle & Promotion of a healthy lifestyle \\
Psychosocial conditions & Significant mental strain & Mental strain \\
& Part of the face covered & Face uncovered \\
Organizational conditions & Testing of children and teachers & No testing of children or teachers \\
Staffing and pedagogical & Changes in the timetable & Changes in the timetable \\
conditions & Significant changes in the & Partial changes in the \\
& implementation of education & implementation of education \\
Parental involvement & Disease and absence of teachers & Disease and absence of teachers \\
& Incompetent cover teaching & Competent cover teaching \\
& More intensive cooperation with & Usual cooperation with parents on \\
& parents on education & education
\end{tabular}

Note: The information in Table 6 is compared in the next section.

\subsubsection{Common and different features of extracted conditions in both countries}

\subsubsection{Material conditions}

Common features: The material conditions in both countries changed because nursery schools had to adjust their environment: greater distances between tables and chairs, disinfection for hands, surfaces and furniture, disposable wipes. The educational environment had to be adjusted so that children were prevented from gathering. The same adjustments applied to spaces for teachers and parents.

Different features: In the Czech Republic, one classroom had to be adapted for testing. Nursery schools had to procure a sufficient number of tests and face masks or respirators. In some cases, aids were added including toys for outdoor education or digital technology for the preparation of distance education. These material changes did not take place in Sweden. 


\subsubsection{Daily regimen}

Common features: In both countries, a healthy lifestyle was promoted including hygiene habits, outdoor activities, vitamin consumption, sports, etc.

Different features: In the Czech Republic, the time spent outdoors increased, while in Sweden four hours outdoors is a standard. In both countries, the anti-epidemic measures recommended that educational activities be implemented outdoors as much as possible.

\subsubsection{Psychosocial requirements}

Common features: The new regulations and different regimen in both countries could have disrupted workplace well-being and increase teachers', children's and families' mental strain.

Different features: In the Czech Republic, the disruption of the psychosocial conditions was caused by mandatory testing of teachers and children, obligation to wear a respirator for employees and parents, preparation and implementation of distance education, change in school-family communication (depersonalization, electronic communication), education outdoors without adequate conditions. In Sweden, education was full-time without mandatory face masks or testing. From this perspective, the psychosocial conditions were not significantly disrupted.

\subsubsection{Organizational conditions}

Common features: In both countries, the arrangement of education changed to prevent children from gathering. These changes related to children's arrival and departure, meals and learning. The education programme was also changed due to sick leaves and frequent cover teaching.

Different features: In the Czech Republic, distance education was ordered and educational activities adjusted. The following activities were prioritized: graphomotor activities, visual arts, physical activity and educational videos. On the contrary, music or group activities were difficult to implement. In Sweden, there were partial changes following the recommended measures and programme adjustments by cover teachers.

\subsubsection{Staffing and pedagogical conditions}

Common features: Both countries had teachers infected with Covid-19 but the rates were not higher compared with other professional groups. Sick teachers had to stay at home for 14 days or longer depending on their health status. They were replaced by cover teachers. Directors were entitled to close down their nursery schools due to the low number of teachers or children. Cover teachers usually had limited preparation time which probably affected the quality of education.

Different features: One of the differences is in the lack of cover teachers. In the Czech Republic, cover teachers were recruited from among teacher training students, babysitters, school assistants. According to the document on volunteering during the pandemic, volunteers had to be qualified and have at least the minimum teacher training course but may not have been fully competent to implement the respective education programme (Vláda, 2020). Sweden has stricter requirements for preschool staff 
(Förordning, 2011). Nursery schools were closed in the case of a higher sick leave and inadequate cover teaching.

\subsubsection{Parental involvement}

Common features: In both countries, parental involvement in school events and their presence in school buildings was restricted.

Different features: More intensive cooperation with parents was observed in the Czech Republic especially during distance education. Parents began to educate their children at home under the guidance of nursery school teachers. The data analysis revealed new information: parental recognition of the teaching profession. In Sweden, the document analysis did not suggest any major changes concerning this condition during the anti-epidemic measures.

\subsection{Analysis of information relating to preparation for compulsory education}

Table 7. Overview changes in preparation for compulsory education during the anti-epidemic measures in both countries

\begin{tabular}{lcc}
\hline Extracted Criteria & Czech Republic & Sweden \\
\hline $\begin{array}{l}\text { Disruption of systematic preparation in } \\
\text { preschool establishments }\end{array}$ & YES & NO \\
$\begin{array}{l}\text { Risk of insufficient school readiness } \\
\begin{array}{l}\text { Postponement of compulsory education due to } \\
\text { anti-epidemic measures }\end{array}\end{array}$ & YES & YES \\
\hline
\end{tabular}

\subsubsection{Disruption of systematic preparation in preschool establishments}

In the Czech Republic and Sweden, systematic preparation for enrolment in primary school was disrupted by the sickness rate of children and teachers, in the Czech Republic also by distance education.

\subsubsection{Risk of insufficient school readiness}

In assessing children's school readiness for primary education, Czech teachers used educational diagnostics implemented in nursery school during full-time education. During distance education, they were not obliged to carry out educational diagnostics. Some children may not have had the ideal conditions for home education and their school readiness may not have been as required. In this case, distance education could have had a negative impact on school readiness, which in some cases may have led to the postponement of compulsory school attendance. In Sweden, educational diagnostics was carried out fulltime throughout the whole epidemic. The great absence of children could have significantly influenced the development of the cognitive area and school readiness. 


\subsubsection{Postponement of school attendance}

During the primary school enrolment procedure in April 2021 in the Czech Republic, an increased number of children with postponement of compulsory school attendance was observed. According to psychologists, the reason is insufficient school readiness in the context of the anti-epidemic measures (Deník Právo, 2021). In Sweden, postponement of compulsory school attendance is not common because systematic preparation is ensured by the preschool class which is the zeroth grade before primary school. Therefore, even during the anti-epidemic measures, there was no significant increase in postponement of compulsory school attendance.

\subsection{Research results formulated through analytical categories}

Table 8. Four analytical categories that present the results of the research

\begin{tabular}{ccccc}
\hline Categories & $\begin{array}{c}\text { Differences in anti- } \\
\text { epidemic measures }\end{array}$ & $\begin{array}{c}\text { Risks to the } \\
\text { educational process }\end{array}$ & $\begin{array}{c}\text { Changes in } \\
\text { educational conditions }\end{array}$ & $\begin{array}{c}\text { Impact on } \\
\text { school readiness }\end{array}$ \\
\hline
\end{tabular}

Note: The juxtapositions (mentioned in Table 5, Table 6, Table 7) and the comparison were used to define the resulting categories.

\section{Conclusion}

The text presents a part of a broader research study that analyses and compares the impacts of the measures against the spread of Covid-19 on preschool education in selected European countries. The text focuses specifically on the analysis and comparison of the impact of the anti-epidemic measures on preschool education in the Czech Republic and Sweden. The results of the narrower research study are presented through the analytical categories.

\subsection{Interpretation of analytical categories}

Analytical categories contain four main areas, as shown in Table 8. Using the resulting categories, we interpret the results of research, which is based on our research problem, research questions.

\subsection{Differences in anti-epidemic measures}

This category focuses on the anti-epidemic measures in both countries as defined in Table 4. The documents clearly show that some of the measures were similar but some were stricter in the Czech Republic than in Sweden. Therefore, preschool education and children's preparation for compulsory school attendance was more strongly influenced in the Czech Republic. In Sweden, the epidemic was tackled differently from the rest of Europe, but still the measures against Covid-19 had a negative effect on preschool education. In conclusion, preschool education was influenced in different ways due to the great differences in the anti-epidemic measures in both countries. 


\subsection{Risks to the educational process}

This category focuses on the affected functions of preschool education as defined in Table 5. The educational process was affected and its fluency with an emphasis on the educational function was jeopardized in both countries. Due to the closure of schools in the Czech Republic, it could be assumed that the educational function could have been affected more in the Czech Republic than in Sweden. On the other hand, the caring function was strengthened in both countries in the context of supporting a healthy lifestyle.

\subsection{Changes in educational conditions}

This category focuses on the affected conditions of preschool education as defined in Table 6 . The extracted and analysed conditions changed considerably as a result of the anti-epidemic measures. At the same time, the changes in the material environment disrupted the psychosocial conditions which in turn affected the organizational conditions. In the Czech Republic and Sweden, the changes in the conditions were similar but thanks to the more stringent anti-epidemic measures in the Czech Republic the changes were more significant, especially the organizational conditions in the context of distance education.

\subsection{Impact on school readiness}

This category focuses on the preparation of children for primary education as defined in Table 7. In both countries there was a risk that the anti-epidemic measures would disrupt children's preparation for enrolment in primary education. In the Czech Republic, the first signs were shown by information from enrolment in primary school which have not yet been statistically processed. However, interviews with psychologists suggest an increase in postponement of school attendance by at least 20\% (Deník Právo, 2021). In Sweden, there is no postponement of school attendance but only potential risks to school readiness. IFAU research shows that the absence of preschool children increased by up to $50 \%$ which could have a negative impact on school readiness of Swedish preschool children and their cognitive development.

\subsection{Research findings and recommendations}

Our research findings and recommendations are not based directly on research questions but only on a research problem. These three categories are a supplement to the research results from Table 8 .

\subsection{Development of digital literacy}

Distance education increased the need for digital technology in the education process. According to the CSI (2020), most Czech nursery schools managed to ensure the education programme supported by digital technology. However, the lack of digital technology in nursery schools and the underdeveloped digital literacy among teachers affected the quality of distance education. It is recommended that digital literacy should be increased among nursery school teachers and future teachers in order for them to be able to pass on the content of education through digital technology (IFAU, 2021). 


\subsection{Increased teacher prestige}

During distance learning in the Czech Republic, parents had the opportunity to experience the process of education. The educational function was partially transferred to parents who educated their children according to teachers' instructions. In this way they saw how demanding the profession of nursery school teachers was and the importance of nursery schools in the development of their children. Increased teacher prestige in the eyes of parents is a benefit (Koželuhová \& Koželuh, 2020).

\subsection{Transfer of the education process into nature}

In both countries it was recommended that as many educational activities as possible should be implemented outdoors. In Sweden, however, this was not a significant change as it is normal to carry out education in nature. In this regard, the Czech Republic could be inspired by Sweden, adjust the conditions of nursery schools and take education to nature. However, this also entails the requirement for the training of future and existing teachers in the area of environmental education, forest pedagogy or research-based education.

\section{Acknowledgments}

The paper was supported by the project IGA_PdF_2021_034 Impacts of the COVID-19 pandemic on pre-school education in selected European countries with an emphasis on preparing children to start compulsory schooling.

\section{References}

Bergkvist, J., Jehrlander, S., Gunnarsson, K., Kancans, A. H., \& Janlöv, N. (2021). Policy Responses in Sweden about Covid-19 - pdf report. Covid-19 Health System Response Monitor. https://www.covid19healthsystem.org/countries/sweden/countrypage.aspx

Bryndová, L., Roubal, T., Poloček, A., \& Žiačik, J. (2021). Policy Responses in Czech Republic about Covid-19 - pdf report. Covid-19 Health System Response Monitor. https://www.covid19 healthsystem.org/countries/czechrepublic/countrypage.aspx

CSI. (2020). Vzděláváni dětí v obdobi nouzového stavu - tematická zpráva [Education of children in times of emergency - thematic report]. https://www.csicr.cz/Csicr/media/Prilohy/PDF_el._publikace /Tematick\%c3\%a9\%20zpr\%c3\%a1vy/Vzdelavani-v-materskych-skolach-v-obdobi-nouzovehostavu-Tematicka-zprava.pdf

Deník Právo (2021). Pandemie se vyř́dila i na nejmenšich, první třídu nezvládnou, bojí se rodiče předškolák [The pandemic has ruled out even the smallest ones, they can't do first grade, preschool parents are afraid]. Deník Právo, 31(153), 4-5.

Förordning (2011). Om behörighet och legitimation för lärare och förskollärare [On eligibility and identification for teachers and preschool teachers]. https://www.riksdagen.se/sv/dokumentlagar/dokument/svensk-forfattningssamling/forordning-2011326-om-behorighet-och_sfs-2011-326

Folkhalsomyndigheten (2020, December 18). Förslag på förebyggande åtgärder i förskolan och grundskolan [Proposals for preventive measures in preschool and primary school]. https://www.folkhalsomyndigheten.se/smittskydd-beredskap/utbrott/aktuellautbrott/covid-19/ verksamheter/information-till-skola-och-forskola-om-den-nya-sjukdomen-covid-19/forebyggandeatgarder-i-for--och-grundskola/ 
Folkhalsomyndigheten. (2021a, February 17). Covid-19 - Förskolor [Covid-19 - Preschools]. https://www. folkhalsomyndigheten.se/smittskydd-beredskap/utbrott/aktuella-utbrott/covid19/verksamheter/ information-till-skola-och-forskola-om-den-nya-sjukdomen-covid-19/forskolor/

Folkhalsomyndigheten. (2021b, April 15). Covid-19 hos barn och unga En kunskapssammanställning Version 3 [Covid-19 in children and adolescents A compilation of knowledge - Version 3.] Artikelnummer: 21092. https://www.folkhalsomyndigheten.se/contentassets/652e21da70bb42bb9d 878d4bdf4f7989/covid-19-hos-barn-och-unga-en-kunskapssammanstallning-version-3.pdf

Gavora, P. (2000). Úvod do pedagogického výzkumu [Introduction to pedagogical research]. Paido.

Ježková, V., Dvořák, D., Greger, D., \& Daun, H. (2011). Školní vzdělávání ve Švédsku [School education in Sweden]. Karolinum.

Koželuhová, E., \& Koželuh, O. (2020). Povinné předškolní vzdělávání skutečnou součástí školského systému nebo formalitou? [Compulsory pre-school education a real part of the school system or a formality?]. Pedagogická orientace, 30(2), 242-248. https://doi.org/10.5817/PedOr2020-2-242

MŠMT (2020). Provoz mateřských škol v obdobi do konce školního roku 2019/2020 [Operation of kindergartens in the period until the end of the school year 2019/2020]. Praha. https://www.msmt.cz /soubor-hygienickych-pokynu-pro-ms-zs-a-ss

MŠMT (2021a, March 1). Doporučení pro vzděláváni distančním způsobem v mateřské škole [Recommendations for distance learning in kindergarten]. Praha. https://koronavirus.edu.cz/files /metodika-ms.pdf

MŠMT (2021b, April). Manuál covid-19 testování ve školách duben 2021 [Manual covid-19 testing in schools April 2021]. Praha. https://testovani.edu.cz/files/msmt-manual-testovani-aktual19-042021.pdf

MŠMT (2021c, April). Provoz škol a školských zařizeni ve školním roce 2020/2021 vzhledem ke covid-19 [Operation of schools and school facilities in the school year 2020/2021 due to covid-19]. Praha. https://testovani.edu.cz/files/msmt-manual-testovani-aktual19-04-2021.pdf

Provázková Stolinská, D., \& Filípková, I. (2021). Komunikace učitele primární školy v odraze aktuálních podminek ve vzdèlávání [Primary school teacher communication in the reflection of current conditions in education. ERIS 21: Aktuální problémy distanční výuky. Hradec Králové: Czech Republic.

RVP PV (2018). Rámcový vzdělávací program pro předškolní vzdělávání [Framework educational program for preschool education]. MŠMT. https://www.msmt.cz/file/45304/

Skolverket. (2011). Läroplan för grundskolan, föskoleklassen och fritidshemmet [Curriculum for primary school, preschool class and after-school center]. Stockholm. https://www.skolverket.se/ undervisning/grundskolan/laroplan-och-kursplaner-for-grundskolan/laroplan-lgr11-forgrundskolan-samt-for-forskoleklassen-och-fritidshemmet

Šmelová, E. (2006). Mateřská škola a její učitelé v podminkách společenských změn: teorie a praxe II [Kindergarten and its teachers in conditions of social change: theory and practice II.]. Univerzita Palackého v Olomouci.

The Institute for Evaluation of Labour Market and Education Policy (IFAU). (2021). Swedish children and youth during the COVID-19 pandemic - Evidence from research on childhood environment, schooling, educational choice and labour market entry. Working paper 2021:3.

Utbildningsdepartementet. (2021). Skollag (2010:800) [School law (2010:800)]. https://lagen.nu/2010:800

Vláda ČR. (2020). Dobrovolnictví vdobě pandemie [Volunteering during a pandemic]. https://www.vlada.cz/assets/ppov/rnno/aktuality/Dobrovolnictvi_v_dobe_pandemie_-_20210219_1_.pdf

Vlček, P. (2015). Srovnávací výzkum v pedagogice - některé úvahy o metodologii problémového prístupu [Comparative research in pedagogy - some considerations on the methodology of the problem approach]. Pedagogická orientace, 25(3), 394-412. https://doi.org/10.5817/PedOr2015-3394

World Health Organization. (2021). Schooling during COVID-19: recommendations from the European Technical Advisory Group for schooling during COVID-19. https://apps.who.int/iris/bitstream/ handle/10665/340872/WHO-EURO-2021-2151-41906-57497-eng.pdf 